\title{
Concreção de fato, valor e norma no direito romano clássico \\ (Ensáio de interpretação ḋ luz da teoria tridimensional do Direito)
}

\section{Miguel Reale}

(Catedrático de Filosofia do Direito)

\section{A fundação da Ciência do Direito}

Uma diferença existe, - atribuivel, talvez, a qualidades próprias das estirpes que constituiram a $U r b s$, embora não seja possivel esquecer as conjunturas históricas iniciais, bem como influências outras de ordem géo-econômicas, uma diferença essencial existe entre o gênio grego e o romano, aquêle orientado mais no sentido da especulaçáo, do saber pelo saber, êste dominado pelos problemas da vida prática, pelas questões postas no domúnio da ação. Dirse-ia que os dois grandes ramos da família ariana traduzem duas tendências fundamentais do espírito, segundo o primado reconhecido ao uso especulativo ou ao uso prático da razão.

De maneira geral, podemos dizer que os helenos teorizaram mais sôbre o Direito e o Justo do que se preocuparam com a elaboração técnica e a compreensão específica das leis diretoras da vida social. Os romanos, homens práticos por excelência, atingiram, ao contrário, pela primeira vez, a noção do Direito como voluntas, sob forma imperativa de regra, sendo levados a discriminar cuidado- 
samente as esferas de atividade permitidas ou proibidas nos limites da utilidade comum, antes de indagarem da razão última da obediência aos preceitos jurídicos. 0 Direito, como conjunto de regras imperativas, apresentouse, desde os primórdios, como algo de conatural ao gênio romano, razão pela qual já se disse que era essa a vocação natural ou a missão histórica da gente do Lácio.

"A Grécia, consoante conhecido cotejo de Villari, raciocina longamente sôbre a índole da sociedade humana, sôbre o homem e a origem do direito, Roma dispõe-se a criar uma sociedade e um direito. Homero, Fídias, Platão e Aristóteles são o resultado da Grécia; a República, o Império, o Corpus juris, são o resultado de Roma". (1).

De certo modo, assim como se fala no "milagre grego" no plano da especulação pura e da expressão artística, como momento decisivo da auto-consciência espiritual e da descoberta do espirito como fôrça constitutiva e original, seria necessário lembrar o "milagre romano" na esfera da praxis, da atualĩzação do pensamento em instituições sociais duradouras, no mundo da vontade, fulcro da experiência humana concreta.

JHERING provocou conhecida celeuma por ter apontado como elemento caracterizador da cultura romana um alto espírito de interêsse bem entendido, ou melhor, de egoísmo capaz dos maiores sacrifícios, por admitir que a verdadeira utilidade consiste nas conquistas lentas e graduais, e

(1) Pasquale Villari - L'Italia e la civiltá, ed. de Giovanni Bonacci, Milão, 1925, pág. 4. Como pondera Pietro de Fraiciscr, a mentalidade realista dos romanos poderia parecer "dom humilde ante o idealismo brilhante e a fantasia criadora dos gregos", mas foi ela que lhes permitiu construir o seu sistema jurídico, cujas linhas gerais são determinadas pelo exame de cada uma das relações reais, ondenadas segundo sua derivação e dependência naturais, em um regime correspondente às respectivas finalidades, assim como às exigências da justiça, da "aequitas", aspiração suprema dos homens. (Storia del diritto romano, Milão, 1944, vol. II, Parte I, pág. 404). 
não na mera satisfação de interêsses imediatos e individualistas. Os romanos teriam, assim, de certo modo, sublimado o seu egoísmo em uma poderosa organização jurídica, visto como, no dizer do mestre germânico, o Direito Romano representaria "o sistema do egoísmo disciplinado", uma sábia dosagem e tutela do útil feita por um povo dotado de egoísmo coletivo, concretizado no egoísmo da Urbs. (2).

Embora não seja de todo possível explicar a grandeza da Jurisprudência romana como conseqüência natural de um sublimado interêsse egoístico, é inegável que ela resultou, em grande parte, da mentalidade pragmática e calculista, "voluntarista" em suma, dessa gente que, depois de conquistar um vasto império, procurou dar-lhe organização e disciplina de base jurídica, objetivando condições. de paz e de progresso, como garantia de domínio menos contestado.

Há um contraste impressionante entre a robustez do: edifício político erguido pelos romanos, a magnitude do Estado romano, unitária e poderosamente constituído sem prejuízo dos usos e costumes e das instituições vigentes nas províncias incorporadas, (3) e o polipeiro de centros políticos que foi o mundo grego, com as suas cidades autárquicas erguidas umas contra as outras, e suas federações urbanas instáveis e passageiras.

o senso da ordem é, geralmente, o senso do Direito. Esse senso ou vontade de coordenação pacífica das atividades não faltou à gente do Lácio, que também não careceu, mas antes se orgulhou, da alta consciência da fôrça e da missão própria do Estado. Daí a importância fundamental que teve entre os romanos o culto do Direito

(2) JHERING - L'esprit du droit romain, trad. de O. de Meulenaere, 3a ed., Paris, 1886, vol. I, § 24. Em sentido análogo, OLIveIra Martins - História da República Romana, 4a ed.; Lisboa, 1927, págs. 24 e segs.

(3) Sôfbre o respeito aos vários direitos locais, v. Arangro Ruız - Storia del diritto romano, Napoles, 5a ed., 1947, pág. 328 e segs. 
e.do Estado, orientando-os no sentido da criação de uma ciência nova, distinta da Ética e da Política, embora a elas subordinada: a Jurisprudência.

Essa compreensão mais direta e especializada dos problemas jurídicos levou os romanos, como veremos logo mais, a aplicar a especulação ético-política dos gregos no sentido particular e próprio do Direito, havendo autores. segundo os quais, se os gregos trataram de Filosofia Política e traçaram uma Ética da Justiça, teria cabido aos romanos aplicar tais conclusões no esboço de uma Filosofia do Direito pròpriamente dita. (4).

Conjunturas históricas predispunham a essa tarefa, desde os primeiros tempos da $U r b s$, quando se abriam as composições jurídico-políticas como via mais segura e aconselhável à solução do conflito entre as estirpes formadoras, primeiro, e, depois, entre as duas camadas da sociedade, o patriciado e a plebe, aquêle tendente a manter os seus privilégios, esta a torná-los também seus.

Frize-se, por conseguinte, que não vemos na história romana a luta de uma classe desejosa de privar a outra de seus privilégios, mas antes animada da aspiração de ver tais privilégios extendidos também a ela.

A luta não podia, pois, se desenvolver senão no sentido de uma permanente composição: composição foi a Lei das XII 'Tábuas, pela qual os plebeus deram um grande passo à frente, visto como se tornava público o Direito anteriormente reservado ao conhecimento esotérito dos pontífices; composição, a posterior ascensão dos plebeus aos cargos. públicos até à conquista das mais altas magistraturas; composição a conquista feita pelos plebeus de direitos de ordem privada, quer familiares quer econômicos, de sorte a se tornarem partícipes do jus civile, reservado às primitivas estirpes de cidadãos romanos; composição a maravilhosa formação do jus gentium através da prudente e

(4) v. ADolfo Ravá - Lezioni di Filosofia del Diritto, I, págs. 56 e segs. 
gradual recepção do direito estrangeiro, polarizado em torno do núcleo essencial do jus romano; composição, por fim, com elementos da especulação helênica, o conceito de jus naturale como cúpula da experiência jurídica multi-secular.

As soluções jurídicas foram, assim, se afirmando segundo as próprias exigências hístórico-sociais, preferido o sentido que os fatos ditavam, sentido eminentemente jurídico porque tôda relação jurídica è uma coordenação atributiva de poderes segundo regras objetivas de proporção. Donde a penetrante observação de Mommsen de que a história romana é "um vasto sistema de incorporações".

Especialíssima é, pois, em Roma a posição do Direito, onde êste foi mais elemento de vida do que objeto de pura especulação. Daí poder dízer-se que os romanos souberam organizar a sociedade juridicamente, fixando linhas mestras ainda hoje inabaláveis para a Ciência do Direito, muito embora a essa criação científica, original e própria, não correspondesse uma indagação filosófica autônoma sôbre o Direito, com igual profundidade, força e originalidade.

Inspirados nas concepções filosóficas da Grécia sôbre os problemas do bem e da justiça, os romanos souberam aplicá-las sábiamente no mundo específico do Direito, mas sem propósitos sistemáticos ou de pura teoria compreensiva da realidade humana. Em verdade, a criação oríginal de Roma foi, acima de tudo, a Jurisprudência, Jurisprudência que êles constituiram através de fino lavor interpretativo das necessidades sociais e econômicas, graças a um trabalho admirável de tipificaçốo normativa, na qual a rigidez aparente das estruturas formais se casava à plasticidade funcional dos fins visados, segundo uma correlação prudente

(5) Th. Mommsen - Histoire romaine, trad. de De Guerle. Paris, s. d., t. I, pág. 100. Oliveira Martrns fala expressivamente em "revoluções constitucionais" de Roma (op. cit., pág. 56). 
entre fato, valor e norma, à medida que se punham exigências de solução de conflitos particulares de interesses. (6)

A aderência à realidade, o apêgo à natureza efetiva $\mathrm{e}$ especifica das relações sociais, determina a formação de uma técnica jurídica não escravizada a conceitos abstratos, mas governada pelo objetivo de satisfazer aos valores da utilitas nos limites éticos da aequitas. Daí duas conseqüências fundamentais, que deveriam ser mais lembradas. por nossos formalistas inveterados: perante as exigências do justo, verificadas em cada caso concreto, não pode prevalecer o amor por formas lógicas vazias, ou por processos dialéticos abstratos, razão pela qual as fictiones, por exemplo, ou as excepções surgiam, não para salvar a harmonia formal dó sistema dogmático, mas para atender aos fatos particulares e ao valor nêles imanente; as generalizações ou as ordenações normativas, surgidas da apreciação direta dos fatos, não passam a valer radicalmente por si mesmas, como dogmas, mas possuem antes uma validez temporária, que não põe termo à incessante pesquiza à luz de novos dados da experiência.

"O realismo dos juristas romanos, daquêles empíricos geniais, escreve DE Francisca, consiste em manter estreitas as relações que unem a idéia ao fato, impedindo que a ruptura dêsse liame acarrete o desvio e a perda de sua eficá-

(6) Sôbre a "configuração por tipos" (tipificação) como elemento da Ciência jurídica, cs. EMILIo BeȚT - Istituzioni di diritto romano, I, págs. 3 e segs. Foi, aliás, meditando sôbre a experiência juridica dos romanos que JHering, na obra já citada, nos legou os primeiros e decisivos ensinamentos sitemáticos de "Técnica Jurídica", cuja importância é invocada por GENY no introito de suas admiráveis páginas sôbre a elaboração técnica do Direito Positivo (Cs. GENy - Science et Technique en droit privé positif, Paris, 1921, III Parte, pág. VII; JeAN DabIN - La Technique de l'élaboration $d u$ droit positif spécialement du droit privé, Bruxelas, Paris, 1935, págs. 4 e segs.)

Quanto à natureza tri-dimensional do Direito. v. Mrguel Reale - Filosofia do Direito, São Paulo, 1953. 
cia". (17) Essa correlação entre o elemento conceitual e o fático é, ao mesmo tempo, integração do elemento finalístico ou axiológico, do objeto, do bonum et aequum que dirige o trabalho da Jurisprudência, impondo uma unidade essencial entre o Direito e a Vida, o que só é possível quando se toma, como diz Biondi a vida tal como ela é, adaptando-se-lhe os esquemas juridicos, de maneira que, não raro, venha a preponderar a communis utilitas sôbre a ratio e até mesmo certos institutos contra tenorem rationis. "Os romanos ensinaram-nos que jus strictum e subtilitas juris, isto é, o Direito lógico e consequente, é superado: pelo ratio aequitatis, pela justiça, à medida que se manifesta o desequilíbrio, sendo sempre a justiça que triunfa, superando a lógica". (8)

o que mais impressiona no processo creativo do Direito é a aderência ao concreto, a vivência do justo, não em abstrato, mas inserido no processo histórico-social, tal como se manifesta notadamente na época clássica, através da interpretatio dos Prudentes. "A disciplina por êles seguida, consoante ponderação de Declareuil, não obstante comportasse variações de detalhes segundo o temperamento de cada um, não admitia nem sistemas, nem construções jurídicas a priori, mas sòmente o estudo de espécies, esclarecido às vezes graças a aproximações ou a comparações entre elas, tendo-se em vista soluções inspiradas apenas pela lógica, pelo bom senso e a analogia. Método analítico, dialético, às vêzes subtíl, sempre claro e tendente ao fim, vasto conjunto de soluções a que recorrer como a um arsenal juridico". Acrescenta Declarevil que, apesar de surgirem, assim, com um caráter eminentemente realista, em função de exigências quotidianas, havia na interpretatio, em-

(7) De Frainciscr, op. cit., vol. I, pág. 18.

(8) Brondo Brond - Scienza giuridica come arte del giusto, em "Jus", Outubro, 1950, pág. 158. Nêste estudo Brondi põe em oportuno realce a concreção axiológica da Jurisprudência romana. não obstante sua compreensão falha da especulação filosófico-juridica e a redução discutível do Direito à "arte do justo". 
bora não deliberadamente propostos, os elementos de sínteses latentes, que constituiam a sua lógica interna.

Ora, tal lógica interna só se tornou possível em razão de uma comum atitude em face dos problemas, traduzindo o valor central de uma cultura, polarizada no sentido da voluntas ordenadora, capaz de compor em harmonia os conflitos, segundo as exigências de uma comunidade concreta, e não em torno de valores explicativos ou compreensivos do logos, expressão essencial da paideia grega.

$\mathrm{O}$ povo grego move-se à luz da ratio, esquematizadora do real, enquanto o romano refoge das atitudes contemplativas frente à vida: seu pensamento já é esbôço de ação.

Dêsse modo, longe de se conservarem no plano explicativo do homem e da natureza, ou na revelação do cosmos através de formas estéticas, - ou seja, no plano da Filosofia e da Arte como comunhão entre o homem e o "eidos" do universo e da existência, - os romanos sentem-se destinados a interferir criadoramente para fundar uma ordem nova, expressão de seus interesses, tradução de sua voluntas. A Política e o Direito de Roma revelam, por assim dizer, desde suas origens, uma fôrça consciente das virtudes do homem como "homo faber", iniciador ou transformador da história.

É claro que em tais esquematizações há sempre certa margem de artifício, mas, sem elas seria difícil surpreender o "espírito de uma época", ou de um tipo de civilização.

Nas culturas dominadas pelo sentido do agir e do edificar, pela voluntas ordenadora, em suma, a tentação estética dos planos ideais céde lugar às soluções empíricas, imediatas, aparentemente desligadas umas das outras, quando não conflitantes, mas, na realidade, fundamentalmente unidas pela consciência volitiva de que tôdas promanam. Daí a impressão posterior de plano e de projeto

(9) v. Declareuil - Rome et l'organisation du droit, Paris, 1924, págs. 423 e seg. 
unitário que se recebe ao contemplar-se a obra realizada, quando, no entanto, veio sendo configurada à lưz das circunstâncias, governada pela força central de uma intenção primordial de ordem.

O que, dêsse modo, caracteriza o mundo jurídico romano é a ausência de esquemas abstratos, de planos preconcebidos. $O$ mesmo se pode dizer de sua existência política, o que levou Bryce, no cotejo que fez entre o voluntarismo essencial dos romanos e o dos inglêses, a Iembrar a frase de Cromwell: "Ninguém vai tão longe como quern não sabe para onde vai". (10)

Sabiam os romanos que havia uma ordem a preservar, uma harmonia de interesses a atingir, e isto era o bastante: daí o já apontado sentido de transigência e de composição, de incorporação crescente de grupos e de classes inferiores na órbita dos interesses e prerrogativas das classes mais altas, de maneira que as revoluções se faziam mais para equiparação de privilégios do que para privar ou excluir alguem dêles.

\section{Do jus civile ao jus raturale}

Como resulta do que acima está dito, os romanos não chegaram ao estudo dos princípios ou fundamentos do Direito senão depoịs de uma pluri-secular experiência juridica. Durante os primeiros séculos, bastou-lhes o seu Direito particularista e próprio, o jus civile, explicado como um conjunto de preceitos estabelecidos "rebus ipsis dictantibus ac necessitate exigente", ou seja, como um produto elaborado na medida das necessidades da vida e da

(10) Cf. J. BRYCE - Imperialismo romano e britannico, trad. it.) Turim, 1907. Além dos Studies in history and jurisprudence de BRYCE, notadamente dos que são objeto da citada tradução italiana, é fundamental para o estudo comparativo do Direito romano e da Common law a obra de W. W. Buckland e A. D. MCinair - Roman Law and Common Law, Cambridge, 1952, 2a ed. 
lição da própria experiência. Para a compreensão dêsse ordenamento jurídico particularista, de cunho acentuadamente aristocrático e formalista, bastava a juris ratio. $O$ que importava aos jurisconsultos romanos era o senso do Direito revelado como experiência concreta, a sábia determinação da razão dos preceitos, a prudente lição das normas vigentes, a hábil concatenação dos dispositivos particulares na configuração dos distintos institutos, em uma palavra, o trabalho consequente do jurispierito, operando com "gêneros" e "espécies" em função da realidade social diretamente vivida.

Como bem observam os historiadores Carlyle, os jurisconsultos romanos não foram própriamente filósofos, havendo pouco ou nenhum traço em suas obras de reflexão original sôbre a natureza da sociedade e as suas instituicões. Na realidade êles foram mais homens de lei, juristas preocupados mais com as necessidades normativas do Direito do que com os problemas filosóficos que a própria existência do Direito sugere. Foi assim que êles percorreram um caminho diverso do seguido pelos gregos: cuidaram antes do Direito Positivo, necessário à ordem social da Urbs e do Império, para depois indagar da razão suprema dos institutos jurídicos. (11)

Estudando o desenvolvimento lento e gradual da Jurisprudência romana, inspirada, a seu ver, em um método histórico e comparativo, o que traduz evidente exagero, - Giuseppe Carle distingue, sem todavia incidir no erro de separá-los rigidamente, três pieriodos ou momentos na história filosófica da Jurisprudência romana: o primeiro é o do jus civile; o segundo é o do jus gentium e o terceiro, do jus naturale. Êsses três períodos distinguir-se-iam pelo

(11) R. W. e A. J. Carlyle - A history of Mediaeval Political Theory, Londres, 1903, vol. I, págs. 34 e segs. 
respectivo predomínio daqueles três conceitos informadores da atividade jurídica. (12)

Sem pretendermos dar um valor excessivo a essa divisão, defeituosa como tôdas as esquematizações da história, podemos dizer que a discriminação dos três períodos correspondem a um "crescendo" de universalismo e de curiosidade especulativa na Jurisprudência romana. Por outro lado, quanto maîs se progride no período post-clássico, mais se acentua o caráter abstrato do jus naturale, contrapondo-se ao jus civile, por sua vez cada vez mais coincidente com a esfera do jus gentium. (13)

Em verdade, o Direito Romano foi, a princípio, eminentemente particularista, apegado não só às fórmulas e aos ritos, como aos imperativos da tradição e do costume. o jus civile, na sua acepção estrita, apresentava-se como o Direito por excéfểncỉa, como um corpo de preceitos reservado à gente romana e destinado a reger tão sòmente as suas relações, como se elas nada tivessem de comum com as dos demais povos. Enquanto predominou o "jus civile" e Roma se manteve dentro de limites geográficos mais ou menos reduzidos, não houve especulação ou "teoria" sôbre o Direito, mas antes o estudo empírico dos casos em razão das regras objeto de interpretação, com a preocupação nunca abandonada de realizar Justiça.

(12) G. CiARLE - La vita del diritto, Turim, 1890, pág. 147.

(13) “Na época justinianea, tornados os súditos livres cidadãos do império, o jus gentium não conserva senão uma importância teórica" (BeTtr, op. cit. pág. 17). No periodo post-clássico, "os vários sistemas jurídicos do jus civile, do jus gentium, do jus honorarium, da cognitio extra ordinem se fundem num único corpo de direito". (Alexandre Ciorreia e Gaetano Sctascia — Manual de Direito Romano, São Paulo, 1949, vol. I, pág. 9). Quanto à posição de Justiniano, vale a precisa afirmação de Koschembahr-LysKowKI: “Justintano tem a concepção da unidade do Direito. Não há senão um Direito privado, sem distinção de jus civile, jus gentium, ou jus pretorium: o que explica ter êle identificado o jus civile com o jus gentium: Jus civile vel gentium. (§ 1, Inst. I, 1) ("Naturalis ratio en droit classique romain", nos "Studi in onore di PIETRo Bonfante", Milão, 1930, vol. III, pág. 486) 
Como tem sido bastas vezes observado, a Jurisprudência romana foi acumulando experimentalmente um gigantesco patrimônio de regras, de preceitos e de institutos jurídicos, e êsse acréscimo de conhecimentos não podia deixar de levar, por exigência natural das cousas, a uma sondagem mais profunda do problema do Direito, a uma penetração na "essencialidade" mesma da Lei e da Justiça.

O certo é que, enquanto Roma se manteve na esfera do jus civile, sem contato relevante e duradouro com ordenamentos sociais de outros povos, seus jurisconsultos se contentaram, como diz Carle, com "a aplicação de um método quase geométrico no estudo da variedade indefinida dos fatos humanos", sem procurar princípios gerais para uma explicação unitária e completa da realidade jurídica. (14) Bastava-lhe a juris ratio, isto é, a penetração na razão lógica do Direito vigente, de maneira que lhes fosse dado proporcionar os institutos jurídicos às exigências mutáveis da vida social, e, ao mesmo tempo, formular o Direito em preceitos precisos, vigorosos, quase escultóreos. Nem é necessário lembrar que foi graças a êsse método ou processo de tipificação e de compreensão concreta da vida econômico-social que os romanos puderam abranger um novo aspécto da experiência humana, constituindo a linguagem do jurista e, com ela, a Ciência do Direito, cuja riqueza lógico-sistemática implícita só viria a ser objeto de "teoria geral" na época moderna, nas obras dos chamados "cultos" ou "humanistas", para afinal adquirir plenitude e maturidade com SAvigny e seus continuadores.

Em verdade, a Ciência do Direito ou Jurisprudência nasceu com os romanos, obedecendo a um processo empírico que, aos poucos, foi se afinando e se elevando até

(14) Op. cit., pág. 148 e segs. "Nos grandes periodos formadores, nem os juristas romanos, nem os nossos (os angro-saxônios) foram grandes teóricos: êles raramente elevavam-se até ao plano dos principios" (Buckland, op. cit., pág. 9). Veremos que esta afirmação não corresponde à experiência total do jus romano. 
possibilitar a ordenação consequente de um conjunto de conceitos rigorosamente talhados, embora sem se integrarem nas linhas compreensivas de uma "teoria", na compreensão unitária da realidade jurídica e de seus pressupostos.

A expansão do Império romano e a subordinação de outras gentes ao domínio da $U r b s$, pondo em contato povos das mais diferentes estirpes e dos mais variados usos e costumes, revelou a existência de um Direito outro que não o romano, ao mesmo tempo que a existência de preceitos comuns a todos os povos. Do contáto do jus civile com o Direito dos estrangeiros é que foí, lenta e prudentemente, se elaborando o jus gentium, quase que um direito commum (quasi quo jure omnes gentes utuntur, no dizer de Ga1o, Inst, I, 1) estruturado sôbre bases fundamentalmente romanas.

A principio, orgulhoso de sua cidadania e de suas peculiaridades, o romano considerou o jus gentium como aquele Direito em que os romanos e os peregrinos coincidiam, um conjunto suplementar de regras para atender sobretudo às necessidades do comércio internacional. Era o Direito que o Pretor, armado de larga autonomia, e fundado na equidade e na boa fé, ia ditando para resolver as pendências surgidas em um campo de interesses incompatível com o formalismo tradicional. Donde o caráter empírico de sua formação tão bem assinalado por Puchta, que nô-lo mostra como produto $\overline{c e}$ uma lenta experiência jurídica, elaborada no mundo romano em virtude de contátos e de confrontos entre as regras do jus civile e as que regiam os povos com que Roma ia entrando em relações militares, mercantís, políticas, etc. (15)

(15) Cs. Puchta - Corso delle istituzioni, trad. de Turchiarulo, Nápoles, 1841, vol. I, págs. 102 e segss. Segunde êsse autor, o jus gentium, longe de ser o fruto de uma simples especulação doutrinária, deduzido de principios abstratos, como o Direito Natural. é um produto histórico, expressão do "espírito do povo romano, 
Tal foi, porém, a riqueza dèsse jus gentium, tal o sentido realista e renovado dêsse direito privado das gentes (16) que, aos poucos, deixou de ser considerado um direito subordinado e secundário, para ser o Direito por excelência, "comum a todos os povos", mas fixado e sistematizado pelo gênio jurídico de Roma. É claro que, na interpretação dêsse Direito, ainda e sempre se continuou a buscar a juris ratio, mas, ao lado dessa indagação, por assim dizer técnica, uma outra se impunha mais lata, tendente a estabelecer o fundamento do jus gentium. E foi assim que, a princípio, se explicou o jus gentium como um Direito fundado no "consenso comum dos povos", explica-

ao avançar em sua civilização", sendo, um "direito romano, embora não consistente de princípios puramente romanos" (págs. 106 e seg.). Também para VoIGT, não é o resultado de Jurisprudência comparada e de especulação racional, mas obra dos próprios jurisconsultoś, "uma produção eminentemente romana" (Das ius naturale, aequum et bonum und ius gentium der Römer, Lípsia, 185675, vol. I, págs. 399 e segs.). É oportuno lembrar aqui que, segundo ilustres romanistas, em nenhum momento do desenvolvimento do Direito romano, teria existido um conceito técnico de jus gentium, entendido como complexo de normas e de institutos aplicáveis às relações entre romanos e peregrinos (Cs. Lombard - Ricerche in tema di "ius gentium", Milão, 1946, págs. 180 e segs.) Fritz Scrrulz, baseado em MitTEIS e KUNKEL diz ser pura fantasia o entendimento do jus gentium como "aquela parte do Direito romano aplicável tanto a cives como a peregrini" (History of roman Legal Science. Oxford, 1946, págs. 73 e 135).

Na realidade, o jus gentium assinala um momento da experiência juridica romana, superando particularismos incompatíveis com os novos tempos, mas não pode ser visto como uma espécie de "sobre-direito", ou de "Direito internacional privado": é Direito romano, não distinto do que era vigente só para os cidadãos romanos, a não ser por seu espírito e sentido universalista. (Cs. JönsKunkel - Derecho Privado Romano, Ed. Labor, trad. de Prieto Castro, 1936, págs. 82 e segs.)

(16) Sentido predominante que, no entanto, não nos deve fazer olvidar outro significado do jus gentium como "primeiro nucleo do Direito Internacional Público". C'f. DE Frax.ISCI — op. cit., vol. II, Parte I, pág. 264 . 
ção esta que bastou enquanto êsse Direito foi se elaborando em virtude da ação criadora do Pretor para dirimir conflitos de interesses entre pessoas pertencentes a ordenamentos jurídicos distintos.

Mais tarde, porém, verificou-se um fenômeno de decisivas consequências para a cultura humana: o contáto da experiência e da técnica jurídica dos romanos com a especulação ético-política dos gregos. Bem poucos assuntos haverá tão relevantes na história do Direito como êsse encontro ou confluência do técnicismo-pragmático romano com a especulação pura dos helenos, assunto que tem sido objeto de estudos magistrais e que não pode deixar de ser apontado como um momento crucial do desenvolvimento filosófico-jurídico.

A apontada origem do jus gentium, correspondente ao sentido de concreção do jurídico e do justo no mundo romano, deve precaver-nos contra qualquer concepção tendente a erradicar a concepção romana de jus naturale de sua circunstancialidade histórica, para só a apreciar como pura categoria abstrata, tal como viria a ser feito pelos bizantinos e por mestres medievais, como SANTo TOMÁs DE Aouino, por exemplo, e já o fora até certo ponto por Cíceno.

Nunca é demais insistir que os cultores do Direito em Roma não cuidaram específicamente de Fĩlosofia, por terem sido precipuamente jurisconsultos, capazes de receberem as idéias filosóficas dominantes no seio da elite romana e de, à sua luz, penetrar na razão íntima dos ordenamentos jurídicos positivos. Homens präticos acinıa de tudo, dominados pelo senso da realização do Direito, os jurisconsultos não se preocuparam com a mera formulação abstrata dos princỉpios primeiros da juridicidade, nem tampouco cuidaram de sistematizar as razões últimas do justo.

Mestres exímios quando se tratava de configurar os dìstintos institutos jurídicos e de esclarecer o sentido orgànico dos dispositivos legais, não se mantiveram no mesmo plano quando a sua atenção foi chamada para os problemas 
fundamentais ou primeiros da Jurisprudência. (17) Entretanto, exatamente por serem jưrisconsultos, a especulação que realizaram sôbre o honesto, o justo e a lei, adquiriu um cunho todo especial, mais novo, por assim dizer mais técnico, orientada no sentido da ordem jurídica positiva, mais do que no sentido da aprecĩação da conduta humana sob o prisma genérico da Ética. O que para uns é especulação pura, para outros é instrumento de ação.

É por êsse motivo que alguns autores declaram que, se os gregos nos legaram obras de Filosofia Política ou de Teoria da Justiça, foram sòmente os romanos que chegaram a conceber a Filcsofía do Direito própriamente dita, o que nos parece deveras excessivo, inclusive pela ausência de qualquer indagação de ordem epistemológica ou deontológica sôbre a Ciência que constituam. Na realidade, é curioso observar que os romanos, que souberam fundar a Jurisprudência e o Império, não nos legaram teorias sôbre ambos. Uma teoria da política imperial procurar-se-á envão no mundo romano, como não se configura, de maneira explícita, a sua teoria geral do Direito. Se CícERo, por exemplo, nas pegadas do grego Políbio, oferece-nos uma teoria política, já é algo que pertence ao passado, ao grande

(17) JöRs e KUNKEL exageram o contraste entre o "primitivismo" das concepções dos juristas romanos no plano das ordenações lógico-sistemáticas ou de ordem geral, e a finura revelada no tratamento das questões particulares: "cada resolução do jurista é, por assim dizer, uma obra de arte, quer por seu acabamento, juridicamente falando, quer por sua forma literária". (Derecho Privado Romano, trad. de Prieto Castro, Ed. Labor, 1937, pág. 37). Parece-nos, no entanto, que essa capacidade de penetrar no valor especíîico de cada porção da realidade social só foi possível porque subordinada a uma compreensão geral da conduta humana, graças a uma "atitude metódica" amadurecida na experiência e, de certa forma, condicionadora de suas expressões particulares e contingentes. Não há como confundir "ausência de teoria geral" com "ausência de princípios", pois êstes os romanos atingiram na esfera juridica de maneira admirável. (Cf. Edouard CuQ - Manuel des institutions juridiques des romainss $2^{\mathrm{a}}$ ed., Paris, 1928, págs. 45 e segs.). 
ideal republicano, ao qual se mantiveram fićis os que não quizeram transpôr o Rubicon seguindo as passadas de CÉSAR.

Dir-se-ia que, sendo protagonistas da História e partícipes ativos do evolver político e social (e não meros espectadores como soem ser os juristas de nossa época, conformados a teorizar sôbre as leis já feitas, oferecidas ao seu cogitar) os jurisconsultos não alcançaram aquela perspectiva que só é atingida por quem, ao menos por exigência metódica, sabe abstrair do viver empírico, para compreendê-lo em sua validade objetiva, em suas "significações universais".

Compreende-se, dêsse modo, a extrema complexidade do problema do jus naturale na Jurisprudência romana, não só para se determinar a sua subordinação às concepções filosóficas da Grécia, como, especialmente, para se saber qual o seu real significado como idéia força na experiência jurídica concreta.

Entrando em contáto com os tesouros da Filosofia helênica, quando já eram possuidores de conhecimentos jurídicos, até então estranhos a todos os povos da antiguidade, era natural que os romanos fossem levados a contemplar os quadros de sua maior criação à luz dos ensinamentos ético-políticos desenvolvidos desde Pitágoras até aos Estói$\cos$, e, através da especulação filosófica, a "dar-se conta" da esfera especifica de cultura por êles revelađa.

Desperta a curiosidade filosófica, ainda que se não empenhasem como filósofos na perquirição dos problemas últimos da juridicidade, os jurisconsultos reconheceram que a idéia de "consenso comum" bastava para explicar empiricamente o fenômeno do jus gentium, mas não era suficiente para explicar a existência de tantos preceitos iguais, estabelecidos por povos pertencentes aos mais diversos quadrantes, sem que êles guardassem notícia alguma de contátos anteriores ou de uma origem comum.

Por outro lado, como observa subtilmente SAvigny, tendo atingido um conceito abstrato de Direito, "comum 
a todos os homens", teriam percebido os jurisconsultos a relatividade dêsse conceito, por ter sido obtido de forma indutiva, com base no conhecimento limitado de alguns povos, e não no de todos: "era natural, todavia, também em razão dessa generalidade apenas relativa, que se elevassem à sua causa originária, e esta foi vista em geral na naturalis ratio, ou seja, na consciência jurídica comum, ingênita na natureza humana." (18).

Se o Direito surgia, por tôda parte obedecendo a um certo número igual de preceitos e se, no jưs gentium, havia normas baseadas apenas no consenso, outras havia como expressão de algo superior à mutável vontade dos povos, o que punha a exigência de um princípio diverso a reger suas concepções.

Daí a idéia de uma naturalis aequitas, contraposta. à civilis aequitas (19) como princípio do jus gentium. Não mais o consenso, mas a naturalis ratio, a identidade da razão e da natureza humana se apresentava como fundamento da ordem jurídica universal.

\section{Jus Naturale e experiência histórica}

Não é de hoje a controvérsia söbre a natureza e a extensão do influxo do pensamento helênico na Ciência jurídica dos romanos. Desde CuJácio e da tradição humanista foi grande a corrente dos que acentuaram essa influência. Ainda Puchta considerava dominante tal opinião entre os doutos, ao escrever as suas Instituições na primeira metade do século passado, e, embora reconhecendo terem sido os jurisconsultos homens instruidos na Retórica e na Dialética, assim como versados nos escritos filosóficos, especialmente nos do Pórtico, nem por isso deixava sem reparo a atitude dos autores que apresentavam

(18) v. Savigny - Sistema del diritto romano attuale, trad. de Scialoja, Turim, 1886, vol. I, pág. 126.

(19) v. Puchta, op, cit., pág. 107. 
a Jurisprudência romana como "emanação da Filosofia estoica", com argumentos por êle considerados extremamente frágeis, frutos da "mania do estoicismo". (20).

Se não pròpriamente a Escola Histórica, pelo menos alguns de seus continuadores, animados de tecnicismo dogmático extremo, favoreceram a opinião oposta de um Direito romano de certa maneira autoctone e autárquico, fechado aos influxos exteriores, pouco ou nada tocado pela força das cogitações filosóficas. (21).

Seria longo lembrar aquí a gama das opiniões sôbre o assunto entre os romanistas atuais, desde os que limitam a influência filosófica (notadamente a estoica) a meros elementos formais, até àqueles que a configuram especialmente no plano metodológico; desde os que a consideram substancial e decisiva na constituição da nova Ciência, até aqueles que vão além, pensando poder identificá-la, de maneira relevante, na vida mesma de certos institutos do jus romano.

(20) Op. cit., vol. I, pág. 147 , § CI.

(21) Não é apenas nêsse ponto que a Escola Histórica revela, paradoxalmente, certa carência de historicidade substancial. CuQ observa com razão que, em um ponto importante, a obra de SAVIGNY marca um recuo com referência à de CuJÁcı: "êle considera a legislação de Justriniano como um conjunto homogêneo; não examina se os textos que cita pertencem a jurisconsultos de épocas ou de opiniões diferentes; êle não se ocupa com a história das doutrinas. Em suma, nos seus trabalhos sôbre Direito romano, é o método dialético que domina, como o verifica R. Vol Jhering, que lhe opõe o método realista". (Cs. EDouARd CuQ - Manuel des institutions juridiques des romains, cit. pág. 73 JHERING - Du rôle de la volonté dans la possession, trad, de Meulenaere, Paris, 1891, págs. VII e VIII). Como mostramos em nossa Filosofia do Direito, São Paulo, 1953, vol. I, t. II, n. 164, essa orientação dialético-formal, inspiradora de uma exegese histórico-dogmática, e não de uma compreensão histórico-cultural dos textos, ia aproximar cada vez mais a Escola Histórica da Escola da Exegese.

Não faltam, porém, na Escola Histórica exemplos de mais profunda compreensão do problema filosófico, como nô-lo demonstra sobretudo a obra de Vorgr, tal como se dirá logo mais. 
Neste, como em outros problemas de interpretação histórica, o variar das doutrinas obedece à diversidade das perspectivas ou da "forma mentis" dos intérpretes. Nada de extraordinário que os "humanistas" da Escola de CuJácio tenham dado tão alto apreço ao inserir-se da problemática filosófica dos helenos na experiência jurídica romana, ou que os "interpolacionistas" contemporâneos, fiéis a um tecnicismo cerrado, hajam renovado o entendimento de um Direito romano formado tão sòmente segundo forças intrínsecas em seu desenvolvimento espiontâ. neo, e pouco sensível às idéias gerais.

Não é demais examinar alguns aspectos dessa questão de tão alta relevância, pois é sempre aconselhável a meditação sôbre o Direito Romano, maximé quando se fala tanto em "crise do Direito", e juristas há a olhar com desconfiança para quantos sustentam ser impossível readquirir-se confiança na Jurisprudência sem a crítica cora josa de seus pressupostos.

O primeiro dado que, nêsse sentido, se nos oferece é quanto à preferência da gente romana por um particular sistema de filosofia, por aquele que estava em consonância com suas tendências peculiares, com o seu nunca abandonado desejo de concreção vital.

Embora seja possível lembrar a influência de AristóTELES mais do que a dos epicuristas (21-A) é, por certo, a doutrina de Crisipo e de ZENo que fascina a maioria dos espíritos, o que se torna compreensivel quando se pensa na propensão romana para uma doutrina mais ética do que metafísica, de princípios morais rígidos e inflexíveis, assinalada pela disciplina da vontade e a apologia da virtude auto-suficiente.

Quem estuda a história romana, forçado é a reconhecer que em Roma houve estóicos antes de serem conhecidos

(21-a) Nesse sentido, v. Helmut CoINg - Zum Einfluss der Philosophie des Aristoteles auf die Entwicklung des römischen Rechts, em "Zeitschrift der Savigny - Stiftung für Rechtsgeschichte", Weimar, 1952, págs. 24 e segs. 
os princípios da Escola, mas é certo que, como acentuam os grandes historiadores do Império, foi na doutrina do Pórtico que os romanos encontraram um elemento poderoso de resistência às forças desagregadoras que iam comprometendo lentamente as suas grandes conquistas militares e políticas.

A Escola estoica, introduzida em Roma por PANecio $\mathrm{e}$ Posinonio, tornou-se desde logo a filosofia da elite romana, grangeando uma posição de absoluto predomínio entre os maiores jurisconsultos, desde Q. Mucio Scaevola, um dos fundadores da Ciência do Direito, até Marciano, desde Rutilio Rufo a Ullaiano.

Nessa recepção de idéias estóicas, cabe, no entanto, levar em conta o modo ou as condições especiais em que o fenômeno se verificou, sendo errôneo apresentar os romanos como simples repetidores das teorias de Zeno e de seus discípulos do mundo helênico.

Ao passo que LAFERrière coloca os jurisconsultos romanos em uma situação de prof́unda subordinação ao pensamento estóico, chegando a sustentar que foi sob a influência dêste que o Direito civil de Roma tomou o nome próprio de Direito Romano (22), estudiosos mais recentes vão reconhecendo que Roma não recebeu passivamente os ensinamentos estóicos, imprimindo-lhes, ao contrário, um sentido novo, de conformidade com a força vital ordenadora de sua concepção da existêncía.

Dilthey chega mesmo a dizer que, quando o estoicisuno penetra na cultura romana, dá-se como que uma devolução, sob formulas filosóficas, de idéias e de concepções inspiradas pelos próprios romanos ao mundo helênico já então sob seu domínio. . "Os mestres, cujas lições Cícero havia seguido, escreve o sutil pensador germânico, quais

(22) Histoire du droit civil de Rome et du droit civil français, Paris, 1846 - vol. II, pág. 192. Cfr. as justas reservas opostas a essa opinião por Alexandre Correia - O conceito de jus naturale, gentium et civile no direito romano, São Paulo, 1934. 
sejam em Roma, especialmente, Froos de Larissa; em Atenas Antioco de Ascalon; e em Rodes, Posidônio -, os livros que utilizou de preferência, pertencem a uma corrente espiritual já condicionada pela enorme impressão que Roma produzia, erguendo-se com o domínio do mundo graças a seus homens de vontade poderosa e às necessidades de sua esplendida juventude". (23).

Até que ponto, no entanto, se exerceu essa influência filosófica no plano da Jurisprudência?

Prevalece, talvez, hoje em dia, superados certos exageros tecnicistas, a opinião de que o pensamento grego influiu na Jurisprudência romana em dois sentidos principais: de maneira geral, como cosmovisão, ou seja, como nova atitude espiritual assumida perante os problemas da existência e do cosmos, o que possibilitou mais clara compreensão da "experiência jurídica" como um dos elementos necessários e comuns a todo o gênero humano; de maneira particular, como tomada de consciência teórica da originalidade e da dignidade científica do labor produzido até então empíričamente na ordenação da conduta humana, pela subordinação da obra realizada a exigências metodológicas de sistematização.

Quanto ao primeiro ponto, não nos parece possa haver, dúvidas, pois não é crivel que Cícero represente um caso isolado na admirável abertura espiritual para os problemas da Filosofia, maximé quando se têm ciência das preocupações especulativas vigentes no Circulo de ScIpiño, centro polarizador dos novos valores culturais. Para empregarmos expressões de Voigr, de significativo sabor savignyano, o Direito, produto do espírito do povo, e a $\mathbf{J u}$ risprudência, parte da ciência geral, não podiam absolutamente escapar aos influxos das forças culturais dominan. tes. (24).

(23) Dilthey - El hombre en los siglos XV e XVI, trad. de Imaz, México, 1944, pág. 23.

(24) Cfr. MonItz VoIGT - Das Jus Naturale, aequum et bonum und jus gentium der Römer, Lipsia, 1856, t. I, págs. 250 e segs. 
No plano metodológico, por outro lado, já no fim da Republica, acentua-se a força renovadora representada pela importação da Dialética dos gregos, cuja adoção abriu à Jurisprudência romana uma nova fase, a da gênese do sistema, o "processo de tipificação conceitual e de ordenação sistemática", não só em virtude das distinctiones segundo gêneros e espécies, como pela procura de princípios informadores, consubstanciados notadamente em definitiones e em regulae juris.

Como observa CuQ, essa transformação de sentido metológico desenvolveu-se sob a dúplice influência da Filosofia e da Retórica dos helenos: "da Filosofia grega os jurisconsultos reeebem a arte de apresentar as regras de direito em ordem sistemática, e de desenvolver suas idéias em ordem lógica; da Retórica, novos princípios de interpretação das leis e dos atos jurídicos”. (25).

No mesmo sentido, põe em realce o papel decisivo da Dialética o romanista Fritz Schulz tanto no "período clássico", como na fase anterior que denomina de "periodo helenístico": "A importação da Dialética, escreve êle, foi um fator do mais alto significado na história da Jurisprudência romana $\Theta$, como consequência, da Jurisprudencia em geral. Ela introduziu a Jurisprudência romana no círculo das ciências profissionais helenísticas e transfromou-a em sua ciência no sentido em que êste termo é empregado por Platão e Aristóteles, assim como por Kant. t tão sòmente uma pesquiza sistemática e um conhecimento organizado que merece receber aquela denominação especial, o que só se tornou possivel, no domínio jurídico, graças ao método dialético". (26).

(25) Cư - op. cit., pág. 40.

(26) Fritz Schulz - History of Roman Legal Science, Oxford, 1946, págs. 62 e segs. 129 e segs. Quanto à influência da Retórica, cf. F. Lanfranchi - Il diritto nei retori romani, Milão, 1938. Relativamente à influência que o estoicismo teria exercido diretamente na determinação ou na compreensão de certos institutos 
Como dissemos, não ficou circunscrita, todavia ao plano puramente metodológico a influência da cogitação filosófica, que gerava fenômeno mais amplo, o da "atitude cultural" ou da consciência primordial dos problemas do destino humano e do destino da Jurisprudência no quadro da existência do homem. Uma cousa é, em verdade, filosofar sôbre o Direito "ex professo" (o que os romanos não fizeram); outra é ter consciência da dignidade da Jurisprudência como experiência humana de significado universal, o que se não pode negar aos romanos, e que êstes atingiram graças ao contacto com o mundo da Filosofia.

O que importa, nêste passo, é caracterizar com precisão o conceito romano de jus naturale, que só aparece como categoria abstrata" ou dado de razão válido por si mesmo. desligado do Direito positivo ou histórico, em periodo tardio de sua evolução jurisprudencial. Na realidade, a não ser na fase post-classica, não se encontra na Jurisprudência romana a doutrina do "jus naturale" como viria a ser desenvolvida na Idade Média, dotado de valor distinto do processo histórico, anterior lógica e ontológicamente ao jus civile e ao jus gentium.

Sua concepção de jus naturale tem validade menos geral do que a pretendida pelas máximas da Filosofia estóica, consoante observação justa de Schulz: é um Direito

jurídicos, v. o estudo de Alexandre Augusto Correia - $O$ estoicismo no Direito Romano, São Paulo, 1950. Parece-nos, porém, tratar-se de influência bem restrita no que se refere pròpriamente à gènese e à configuração dos institutos, embora se apresente mais acentuado no período post-classico. A maior parte dos textos invocados em apôio de uma influência específica, em determinadas categorias jurídicas, estão sujeitos a fortes dúvidas quanto a acréscimos ou a alterações introduzidas na época justinianea, tal como ocorre especialmente em matéria de direito de pessoas e de família, ou tôda vez que prevalecem os conceitos de humanitas ou de pietas. Cf., em geral, Bonfante - Lezioni di storia del diritto romano, Roma, I Parte, págs. 103 e segs; Albertario - Studi di diritto romano, cit., vol. V; Schulz - I principii del diritto romano, cit., págs. 164 e segs. 
Natural que "permanece enquadrado na legislação romana. mantendo intangiveis certos conceitos fundamentais e certas máximas axiomáticas tradicionais; é, em suma, um Direito Natural romano, que carece da força especulativa do Direito Natural dos gregos". (27).

Quem, a nosso ver, soube caracterizar bem a conexão essencial entre o jus naturale e a história na concepção dos romanos foi Moritz VoIGT, cujo pensamento não nos parece tenha sido plenamente apreendido por V. CathreIn, partidário de um Direito Natural abstrato, válido com anterioridade a todo processo histórico. Segundo Cathrein, o citado romanista teria afirmado que os jurisconsultos haviam entendido o jus naturale et gentium tão sòmente como um Direito ideal ou potencial. e não como um verdadeiro e válido Direito. Na realidade, o jus naturale romano, na interpretação de VorGit, apresenta-se com um duplo significado, no plano puramente especulativo e teorético, e também no plano empírico e prático, valendo como norma ideal e como ordenação a seu modo positiva. Os dois conceitos implicam-se. dada a conerão entre o elemento ideal e o elemento histórico, em relação ao qual aquêle se põe como potência condicionadora. (28).

É êsse sentido concreto do jus naturale, como algo de inseparável da experiência histórica do jus, que, a nosso ver caracteriza o Direito Romano clássico, em contraste com o conceito abstrato do jus naturale na época seguinte, notadamente no chamado "Direito romano cristão.". Nêsse ponto. em obra recente. Francisco Calasso cerrelaciona a problemática do jus naturale e a da aequitas. mostrando que esta. nos textos juristinianeus, representa "um princípio ideal de justiça humana", composta de elementos jurídicos e meta-jurídicos, superior ao jus e para o qual o

(27) F. Schulz - I principii del diritto romano, trad. de Vicenzo Arangio Ruiz, Florence, 1949, pág. 29.

(28) Moritz Voigt - op. cit., vol. I, págs. 332 e segs. Cfs. Cathrein - Filosofia del derecho, el derecho natural y el positivo, trad. de Jardon e Barja, Madrid, 3.a ed., 1940, pág. 173. 
jus deve tender, enquanto que, antes, no Direito clássico, a aequitas havia designado um principio singularmente jurídico, o fin supremo ou a força ideal que informa todo o sistema do Direito positivo (29). Até mesmo Cícero, apesar de sua compreensão filosófica do jus naturale como ideal válido em si mesmo (compreensão esta que só logrará ressonância entre juristas no período romano-cristâo) podia definir o jus civile como "aequitas constituta iis qui eiusdem civitatis sunt" (30). Dêsse modo, como ainda observa Callasso, a aequitas dos clássicos era, genuinamente, algo de intrínseco ao próprio sistema do Direito positivo, e não de transcendente ou de superior a êste. A tal ponto que uma antitese entre aequitas e jus só era concebivel, como discrepância entre uma norma, singularmente considerada, e a totalidade do sistema jurídico. (31).

Compreende-se, pois, que o jus naturale não possa ser concebidos pelos clássicos, em geral, senão em função do jus gentium, prevalecendo o sentimento de uma implicação entre o elemento ideal e o histórico, embora sem uma explicação doutrinárỉa esclarecedora. Já na época justiniana o Direito Natural adquire uma validade própria como ditame da Divina Providência e entidade não só primordial como perfeita. (32).

A disputa ainda aberta entre romanistas para saber se o jus naturale chegou a constituir uma terceira categoria ao lado do jus gentium, ou se, ao contrário, com êste se confundia, não raro olvida que se trata de dois aspectos

(29) Francesco Calasso - Medio Evo del diritto, Milão, 1954, vol. I, pág. 332. Cif. o sempre atual estudo de ScialoJa - Del diritto positivo e dell'equitá, em "Studi Giuridici", Roma, 1932, vol. III, págs. 1-23.

(30) Cí́cero - Topica, 2, 9.

(31) Calasso, loc. cit.

(32) Sôbre a diferença entre o jus naturale clássico e o justinianeu, vide Brondo Brond - II diritto romano cristiano, Milão, 1952, vol. II, págs. 4 usque 27, e Albertario, op. cit., vol. V, págs. 277 e segs. 
de uma mesma questão, vista como categoria histórica (jus gentium) e, ao mesmo tempo e inseparavelmente como exigéncia ideal (jus naturale), o que nos preserva de certa tendência a empobrecer o conceito de jus naturale até reduzí-lo ao complexo de elementos biológicos, fisiológicos, "naturais", em suma, que necessariamente sempre condicionam a vida do Direito.

O reconhecimento dessa funcionalidade entre jus naturale e jus gentium no processo evolutivo da cultura jurídica romana talvez possa lançar nova luz sôbre o intrincado problema da divisão dicotômica ou tricôtomica do jus em Roma.

Os romanistas, com efeito, até hoje discutem sôbre quais teriam sido os partidários de uma ou de outra corrente... Tal colocação do problema, feita através de méro jogo formal de combinações e de cotejos de textos, tem possibilitado e ainda possibilitará as mais desencontradas opiniões.

Até mesmo quanto a Cícero, mais filósofo do que jurisconsulto, haverá divergência, uns apontando o autor do De legibus como sendo partidário da distinção tripartita (jus naturale, juts gentium et jus civile) como fazem, por exemplo Emílio Costa, Giorgio del Vecchio e P. Krueger (33) enquanto outros poderão considerá-lo adepto da dicotomia jus civile et jus gentium (= jus naturale) como é o caso de H. F. Jolowicz e de Arangio Ruiz. (34).

(33) E. Cos'ra - Cicerone giureconsulto, Bolonha, vol. I, pág. 26. Dex Vecchio - Lezioni di Filosofia del diritto, 9.a ed., Roma, 1953, pág. 34: "entre êsses termos não há contradição, sendo antes determinações graduais de um mesmo princípio”, P. KRUEGER Histoire des sources du droit romain, trad. Brissaud, Paris, pág. 55.

(34) H. F. JoLowicz - Historical introduction to the study of Roman Law, Cambridge University, 1952, págs. 104 e seg., Arangro Ruiz - Istituzioni di diritto romano, Napoles, 1946, págs. 25 e 27. 
A divergência surgirá também com relação a Ulpiano, não só para se considerar isolada e de insignificante ressonância a sua concepção tricotômica, como também para se contestar a existência de uma sua distinção efetiva entre ju's nautrale e jus gentim. (35).

Por outro lado, não nos parece possa resolver substancialmente o problema a tese dos que excluem do periodo clássico o conceito mesmo de jus naturale, quer na acepção de Ulpiano (quod natura omnia animalia docuit, D. 1, 1, § 3) quer na mais precisa de Paulo (quod semper bonum et aequ'm est, D. 1, 1, 11) por se considerarem interpolados todos os textos em questẫo, seja pelos compiladores bizantinos (36) seja em virtude de glosas escolásticas pré-justinianeas. (37). Na verdade, ainda que fosse posterior o emprego do termo jus naturale, torna-se dificil contestar que o termo jus gentium já não possuisse, na época clássica, duas acepcões distintas, uma histórica e uma outra que alguns denominam dogmática, mas que será melhor considerar ética, dada a invocação da naturalis ratio como expressão do sentimento jurídico comum entre povos do mesmo grau de civilização.

Os dois significados, mesmo quando alguns poucos jurisconsultos chegam a distinguí-los nas categorias do jus gentium e do jus naturale, permanecem sempre inter-ligados. dado o sentido de integração fático-axiológico-normativa que caracteriza a Jurisprudência romana, a respeito

(35) No sentido da tricotomia, v. Alexalndre CỏnrêA, op. cit. e a correspondente bibliografia. Pela tese contrária, segundo a qual Ulpiano não discreparia da identificação corrente entre jus naturale e jus gentium. cf. S. PERozzi - Istituzioni di diritto romano, Milão, 1947, pág. 91 n. 2. A nosso ver, ambas as posições partem de pressupostos formais, pondo entre parêntesis a correlação unitária e necessária dos dois conceitos.

(36) Cf. Perozzi op. cit., pág. 66, n. 1. Contra, Pacchioni, Corso di diritto romano, I, pág. 305.

(37) Arangio Ruiz - Insituzioni di diritto, romano, cit. pág. 26. 
da qual já foi possivel invocar a concepção de um Direito Natural de conteúdo variável. (38).

Eecessário, pois, recorrer à compreensão históricocultural do problema, ao sentido dominante do Direito romano como experiência concreta. A essa luz, parece-nos inegável que a correlação do jus naturale com os elementos históricos devia traduzir-se, na mente dos jurisconsultos, em uma correlação entre jus naturale e jus gentium, como categorias só compreensiveis em função dos fatos históricos.

Elaro que nos referimos apenas à época clássica, na qual pode-se dizer que os valores éticos, as exigências da aequitas estão imanentes no processo da positividade jurídica, condicionando-a no âmago da evolução do Direito, com aquela dupla fonte de justiça concreta que foram o pretor e o jurisconsulto. $\mathrm{O}$ mesmo não acontecerá mais quando outros ambientes culturais determinarem diferentes formas de enlace entre os inevitáveis elementos de tôda vida juridica, fato, valor e norma.

Nem séria lícito afirmar-se, de maneira absoluta, que depois se passou para um fase de decadência, caracterizada por uma compreensão abstrata do Direito, sem a integração concreta dos três elementos em um plano de imanência histórica, devido a uma hierarquia de planos, prevalecendo o elemento ideal, como tal, ao qual deveriam se ajustar as esquematizações jurídicas positivas. A decadência manifestou-se no plano doutrinário e científico, é certo, logo após Ulpiano e Paulo, acompanhando a crise de uma cultura e de uma civilização, mas outras soluções se delineariam no bojo dos acontecimentos, ao rítmo de outras exigências espirituais, ditando outros processos de enlace entre - Direito e a Vida. o Direito e os fins que os homens acaletam.

(38) Nesse sentido De Franiciscr, op. cit,, vol. I, pág. 12, nota. Cf. também Bonfante, Scritti, págs. 6 e 19 . 
À medida que o Direito romano foi deixando de ser experiência vivida. história operante nas revisões e nas adaptações práticas dos institutos, segundo o variar das oportunidades e das necessidades concretas, para cristalizar-se em fórmulas rígidas por ter-se esgotado a fonte reveladora dos institutos, ou pelo advento de novos fatores de perturbação na multi-secular continuidade jurídico-normativa; à medida que as antigas categorias se divorciavam das condições existentenciais, e a prática burocrática predominava sôbre o gênio criador, o jus naturale ia sendo também projetado ou extrapolado para um plano distinto do pertinente ao Direito positivo, de sua condicionalidade histórica, para passar a valer como entidade "a se stante".

O que Cícero, como filósofo, já de certo modo concebera, ou seja, a validade abstrata da lei natural, ia encontrar ambiente favorável de aceitação no plano empírico da Jurisprudência, quando os juristas post-classicos, no setor mesmo da vida prática, não podiam deixar de reconhecer o contraste entre o ideal e o real, máxime quando o ideal se thes projetava nas coordenadas novas da vida cristã, segundo uma hierarquia de fins totalmente diversos dos acalentados pelos mestres da melhor Jurisprudência romana. Assim acontece sempre: quando novos valores são reconhecidos como fins fundantes de uma civilização, assumem êles uma validez abstrata com relação às normas positivas ainda vigentes. (39).

Ideal e real foram vistos, na epoca post-classica, de uma forma por assim dizer estática, como se houvesse entre "jus naturale" e "jus gentium" planos justapostos. Essa superposição os jurisconsultos antigos haviam sabido evitar, não negando a antítese, mas inserindo-a na força imanente do processo histórico.

(39) Sôbre a relação entre valor e fim, e sua consequência para uma compreensão tudimensional específica e concreta do Direito, vide Miguel Reale - Filosofia do Direito, cit. vol. I, t. II. 
Entre a concepção humanista e concreta do jus naturale, vigorante no mundo dos jurisconsultos clássicos, e a concepção cada vez mais abstrata do mesmo jus naturale, até culminar na teoria providencialista e transcendente de Justiniano, forçoso é, pois, reconhecer a verificação de um processo de desajustamento e de desconexão de categorias à realidade histórica, de alteração profunda no valor semantico dos vocábulos.

A idéia de um jus naturale a-histórico, porque de origem divina, transcendente e superior ao direito positivo, constituiu valor novo na história da cultura, coincidindo com o fim da Jurisprudência estritamente romana. Concebê-lo nos limites da experiência jurídica da época republicana e dos primeiros séculos do Império seria forçar a realidade histórica, esquecendo-se os valores vitais que quizemos pôr em realce nestas notas de estudo.

São Paulo, Novembro de 1954 